\title{
1 Perceived disrespect and abuse among women delivering at 2 a tertiary care center in Nepal
}

3 Sabika Munikar $^{1 \text { II* }^{*}}$, Mala Chalise ${ }^{2 \mathbb{\pi}}$, Ranjan Dhungana ${ }^{3 \pi}$, Durga Laxmi Shrestha ${ }^{4}$, Naresh Pratap

$4 \quad \mathrm{KC}^{3}$, Animesh Dhungana ${ }^{3,}$ Robert B. Clark ${ }^{5}$, Michael K. Visick ${ }^{6}$, Kanchan Thapa ${ }^{3,7 \pi}$

$5{ }^{1}$ Post Basic Bachelor of Nursing Science Faculty, Om Health Campus, Kathmandu, Nepal

$6 \quad 2$ Independent Researcher from Kathmandu, Nepal.

$7 \quad{ }^{3}$ Helping Babies Breathe (HBB) Program, Safa Sunaulo Nepal, Kathmandu, Nepal

$8 \quad{ }^{4}$ Ministry of Health and Population, Nepal

$9{ }^{5}$ Department of Public Health, Brigham Young University, Provo, Utah, USA.

${ }^{6}$ Department of Pediatrics, University of Utah School of Medicine, Utah, USA.

${ }^{7}$ Central Department of Population Studies, Tribhuvan University, Kathmandu, Nepal.

*Correspondence: mesabika@gmail.com (SM)

$14{ }^{\mathrm{II}}$ These authors contributed equally to this work. 


\section{Abstract}

\section{Background}

23 Of the children born every year in Nepal, $57.4 \%$ are delivered in health facilities. Disrespect and

24 abuse of women during maternity care are problems that can significantly impact women's

25 willingness to seek out life-saving maternity care. However, evidence suggests ongoing

26 disrespectful maternity care worldwide. This study aims to identify perceived disrespect and

27 abuse during labor and delivery among postnatal women delivering at Bheri Hospital, Nepal.

\section{Methods}

29 A cross sectional study was conducted among 445 purposively selected women admitted in

30 postnatal ward of Bheri Hospital, Nepal from February to March 2020. Ethical approval was obtained from Nepal Health Research Council. Informed written consent was obtained from each participant and a face-to-face interview was conducted for data collection. A semi-structured questionnaire consisting of demographic information and a pre-validated Respectful Maternity

34 Care (RMC) tool was used. The information was then checked, coded, and entered in SPSS for 35 descriptive and inferential analysis.

\section{Results}

37 In this study, the participants perceived very high friendly care, abuse-free care and discrimination-free care but moderate timely care only. Timely care was found to be significantly associated with age, ethnicity, occupation, monthly income, gravida, type of delivery, and complications. On multinomial regression, monthly income and type of delivery were the only

42 times more likely to have neutral RMC, and those who earn less than twenty thousand Nepalese 
medRxiv preprint doi: https://doi.org/10.1101/2021.01.23.21250363; this version posted January 27, 2021. The copyright holder for this preprint

(which was not certified by peer review) is the author/funder, who has granted medRxiv a license to display the preprint in perpetuity.

It is made available under a CC-BY-NC-ND 4.0 International license.

\section{Conclusion}

45 This study concludes that disrespectful or abusive maternal care is not perceived among women

46 delivering at Bheri Hospital in terms of friendly care, abuse-free care and non- discriminatory

47 care. However, timely care is less reported. Appropriate interventions to provide timely care to

48 delivering women must be instituted.

49 Key words: Delivery; Disrespect and abuse; Labor; Maternal health services; Respectful

50

maternity care; Midwives

51

52

53

54

55

56

57

58

59

60

61 


\section{Introduction}

63 With Maternal Mortality Ratio (MMR) at 239 per 100,000 live births in 2016- higher than its

64 South Asian neighbors- maternal mortality remains a formidable challenge in Nepal. Although

65 the country has witnessed considerable decline in MMR by 55\% from 1996 to 2016 [1], it still

66 needs to go a long way to achieve the target of 70 per 100,000 live births as set out in the

67 Sustainable Development Goals (SDGs) [2].

68 Ensuring access to quality skilled care before, during, and after childbirth is vital in reducing maternal mortality [3]. In low resource settings such as Nepal the lack of availability of skilled care services, mistreatment during childbirth, including abusive, neglectful, or disrespectful care may result in compromised quality [4]. Women have experienced disrespect and abuse (D \&A)

72 all over the world in various forms ranging from physical or verbal abuse, stigma or

73 discrimination [4], detention of babies [4], being shouted at [5], threatening comments [5], withholding procedure related information and providing non-consented care [5]. For instance, a

75 study in Ghana revealed that only a few clients were encouraged to ask questions and explained what to expect during labor [4]. Non-confidential care has also been reported [6], as identified in

77 a study conducted in India. Similarly, evidences suggest that women have also experienced poor quality care in the form of restriction in their choice of birth position and movement, and restriction of liquid drinks during delivery [7].

Although a growing body of evidence paints a disturbing picture of women's experience of care during pregnancy and child birth, health care providers justify such acts on the grounds of punishment for non-cooperation from women and good outcomes to babies[4]. Analyzed from the perspective of health service delivery system, difficult circumstances in health facilities under which maternity staffs work, system failures, and inadequate human resource management 
85 have been found as important reasons for D\&A during delivery [8]. However, justifying disrespectful care and abuse based on these factors is a violation of women's human rights.

87 RMC has been defined by World Health Organization (WHO) as "care organized for and provided to all women in a manner that maintains their dignity, privacy, and confidentiality, ensures freedom from harm and mistreatment, and enables informed choice, and continuous support during labor and childbirth" [9]. In this sense, RMC focuses on expanding safe motherhood beyond prevention of maternal mortality and morbidity to incorporate a human-

92 rights based approach, including respect to women's autonomy, dignity, choices, privacy and 93 preferences [10]. RMC recognizes that all women need and deserve respectful care; and focuses

94 on eliminating D\&A during pregnancy and childbirth.

95 Despite the existing evidences that suggest D\&A during childbirth presents considerable

96 impediments to utilization of skilled birth care globally [9], only a few studies have been

97 undertaken to understand the phenomena in Nepal. The majority of these studies have used a

98 qualitative approach and only a limited number of studies have used a validated quantitative tool

99 to measure the level of D\&A at the point of service provision, out of which the greater number

100 are based on health facilities in Kathmandu Valley.

101 This study aimed to identify perceived D\&A during labor and deliveries among postnatal women

102 admitted at a remote hospital and also determine the factors affecting RMC. Understanding

103 women's perspective of D\&A during care is essential to identify factors that generate RMC in

104 the health facility and subsequently in the provision of RMC as envisioned in The Right to Safe

105 Motherhood and Reproductive Health Act of 2018. 


\section{Methods}

\section{Study Design, Study Setting and Sample Size}

A cross-sectional study was done to identify the forms and associated risk factors of perceived disrespect and abuse among women delivering at Bheri Hospital, Nepal. With 5083 deliveries conducted in the year 2017-18 [11], Bheri Hospital in southwestern Nepal is a major referral center for emergency obstetric care services for three out of seven provinces (Lumbini Province, Karnali Province \& Sudur Pachhim Province) of the country.

The sample size was calculated based on a study conducted in India, Ghana, and Kenya which depicted an overall prevalence of verbal abuse to be $16 \%$ across all countries [6]. Considering the prevalence of verbal abuse to be $16 \%$, and level of significance to be $95 \%$, the minimum sample size for the proposed study was calculated to be 237 . However, we were able to collect the information from 445 women who delivered during the allocated period of data collection.

\section{Study Participants and Recruitment}

119 Purposive sampling technique was used to interview postnatal women admitted at the postnatal ward of Bheri Hospital, within 24 hours of delivery. Those who were unwilling to participate in

121 the study, couldn't understand and/or speak the Nepali language or had a stillbirth or macerated 122 birth during delivery were excluded from the study.

\section{Data Collection}

124 Face-to-face interview technique was used to collect data. Each interview lasted for

125 approximately 20 minutes and conducted in the Nepali language. The data were collected from

126 February to March 2020. Informed written consent was obtained before data collection. Data

127 were collected from women in postnatal ward within 24 hours of delivery to avoid recall bias. 
medRxiv preprint doi: https://doi.org/10.1101/2021.01.23.21250363; this version posted January 27, 2021. The copyright holder for this preprint (which was not certified by peer review) is the author/funder, who has granted medRxiv a license to display the preprint in perpetuity.

It is made available under a CC-BY-NC-ND 4.0 International license.

A semi-structured questionnaire, divided into two parts, was used as the tool for data collection.

The first part included questions relating to socio-demographic factors and obstetric history, details of which are presented in Table 1. The second part of the questionnaire was based on a validated RMC tool with 15 items used to measure women's perception regarding RMC. The tool has four dimensions: friendly care, abuse-free care, timely care and non-discriminatory care consisting of 7, 3, 3 and 2 items, respectively [12]. The construct validity of the scale is confirmed by the high average factor loading of the four components ranging from 0.76 to 0.82 and a low correlation between the components. The scale has adequate reliability with $\alpha=$ $0.845[13]$. The instrument was translated into the Nepali language and validated by a Nepali language expert. The content validity of the instrument was established by consultation with subject experts. Consistency of the tool was checked by pre-testing among $10 \%$ of women delivering at Bheri Hospital which was not included in the final study sample.

\section{Data Analysis}

The collected data was checked, organized and coded, and entered into Microsoft excel and then exported to SPSS (Statistical Package for the Social Sciences) 17.0 version for analysis. The data were analyzed by using descriptive statistics like frequency, percentage, mean, standard deviation, and inferential statistics: chi-square test, and multinomial logistic regression.

Mean score (M) of four broad components i.e. friendly care, timely care, abuse free care, and non- discriminatory care was used to describe the level of respectful maternity care experienced by the postpartum women during childbirth in each component separately. To determine the participant's degree of respectful maternity care, the following Likert- range conversion and qualitative interpretation were used: 4.20- 5.00-Very High, 3.4- 4.19 -High, 2.60- 3.3 - Moderate, 1.80- 2.5 -Low and 1- 1.78 Very Low [12]. 


\section{Ethical Approval}

152 Ethical approval was obtained from the Nepal Health Research Council (Ref \#1953, 18 March

153 2020). Written permission from Bheri Hospital administration was also obtained. Informed

154 written consent was obtained from the respondents. Participants were also assured that their

155 participation/non-participation would have no bearing on their treatment. Confidentiality of the

156 participants was maintained by assigning unique identification code to each participant.

\section{Results}

158 Table 2 depicts the socio-demographic information of the participants. The majority of them

159 (74.4\%) were aged 20- 30 years, belonged to the Janjati ethnic group (46.1\%), and most of them

$160(91.2 \%)$ followed the Hindu religion. The majority $(86.7 \%)$ were educated. However, almost half

$161(50.8 \%)$ were unemployed. Approximately fifty-three percent of respondents were from joint or

162 extended family. Regarding the spouse's background, most of them (91.7\%) were educated and

163 were involved in a non-formal occupation (71.5\%).

164 Table 3 illustrates the obstetric history of participants. The majority of participants had less than

165 two gravidae (75.7\%), were multiparous (64.7\%) and most of them $(95.7 \%)$ had term pregnancy.

166 Almost half of the participants (51.5\%) delivered via spontaneous vaginal delivery (SVD) while

167 remaining delivered via augmented labor and/or lower section cesarean section. One third of

168 respondents (33.3\%) had complications during labor.

Table 4 shows the perception of participants regarding RMC on a 5 points Likert scale. The

170 components of RMC are presented in four broad categories of Friendly Care, Abuse-free Care,

171 Timely Care, and Non-discriminatory Care.

172 Regarding Friendly Care, very few respondents disagreed that the health workers cared for them

173 with kind approach $(0.9 \%)$, treated them in a friendly manner $(2.6 \%)$, talked positively about the 
174 pain and relief measures $(2.0 \%)$, showed concern and empathy $(0.2 \%)$, treated them with respect 175 as an individual (1.5\%), and spoke in understandable language (10.5\%). Of note, almost half of 176 the participants $(47.2 \%)$ disagreed on being called by their name.

177 The table also presents the perception of participants towards Abuse-free Care. Nearly $32.6 \%$

178 disagreed with the statement that health workers responded to their needs whether or not asked.

179 Also, 5.6\% reported being slapped during delivery for different reasons, and a similar number of 180 participants $(4.7 \%)$ reported being shouted at for not doing what they were told to do.

181 Regarding Timely Care, more than a quarter of participants (27.8\%) agreed to being kept waiting

182 for a long time before receiving care, but a higher number of participants were not allowed to

183 practice cultural rituals $(62 \%)$. Some agreed that service was delayed due to health facility's 184 internal problems (18.7\%).

185 Perception towards Discrimination-free Care shows that few respondents (3.3\%) agreed that the 186 health workers did not treat them well because of personal attributes. Also, 2.9\% of participants 187 agreed that some health workers insulted them and their companions due to personal attributes.

188 The mean score shows that the participants' perceptions of Non-discrimination Care (4.67), 189 Friendly Care (4.42) and Abuse-free Care (4.29) were very high, whereas perception of Timely 190 Care (3.10) was comparatively moderate. 
medRxiv preprint doi: https://doi.org/10.1101/2021.01.23.21250363; this version posted January 27, 2021. The copyright holder for this preprint (which was not certified by peer review) is the author/funder, who has granted medRxiv a license to display the preprint in perpetuity.

It is made available under a CC-BY-NC-ND 4.0 International license.

191 Table 4 presents the findings of the association between selected demographic and obstetric

192 characteristics and the Friendly Care component of RMC. This table shows that there is a

193 significant association between timely care and monthly income $(\mathrm{p}<0.05)$, gravida $(\mathrm{p}<0.05)$, para

$194(\mathrm{p}=0.004)$, and week of gestation $(\mathrm{p}=0.026)$.

195 Table 6 reveals the association between Abuse-free Care and selected demographic and obstetric

196 characteristics. This table shows that there is a significant association between Abuse-free Care

197 and spouse's occupation $(\mathrm{p}=0.002)$, para $(\mathrm{p}=0.010)$, type of delivery $(\mathrm{p}<0.05)$.

198 Table 7 shows the association between Timely Care and selected characteristics which reveals

199 that there is a significant association between Timely Care and age $(\mathrm{P}<0.05)$, ethnicity $(\mathrm{p}=0.002)$,

200 occupation $(\mathrm{p}=0.001)$, monthly income $(\mathrm{p}<0.05)$, gravida $(\mathrm{p}<0.05)$, type of delivery $(\mathrm{p}=0.002)$,

201 and complications ( $\mathrm{p}=0.002)$. However, there is no significant association between Timely Care

202 and educational status, spouse's occupation, or week of gestation $(\mathrm{P}>0.05)$.

203 As mentioned in Table 4, among the four components, women's perception of Timely Care was

204 found to be moderate whereas other dimensions of RMC were perceived very high. To determine

205 the factors resulting in moderate perception of Timely Care, multinomial logistic regression was

206 done. Table 8 shows that those who had SVD were 2.07 times as likely to have neutral RMC for

207 Timely Care. Similarly, those who earn less than twenty thousand Nepalese Rupees per month

208 were 2.36 (1.30-4.23) times as likely to have high Timely RMC in Nepal. We did not observe

209 any significant effects between gravida, complication during the delivery, and the number of

210 living children $(\mathrm{P}>0.05)$.

\section{Discussion}

212 This study aimed to identify perceived Disrespect \& Abuse and its associated factors during

213 labor and delivery among postnatal women at a busy referral hospital in western Nepal. D\&A are 
medRxiv preprint doi: https://doi.org/10.1101/2021.01.23.21250363; this version posted January 27, 2021. The copyright holder for this preprint (which was not certified by peer review) is the author/funder, who has granted medRxiv a license to display the preprint in perpetuity.

It is made available under a CC-BY-NC-ND 4.0 International license .

214 evaluated based on four different dimensions of RMC i.e. Friendly Care, Abuse-free Care,

215 Timely Care and Discrimination-free Care. Very high degree of Friendly Care, Abuse-free Care

216 and Discrimination-free Care was identified, however, only moderate Timely Care was

217 perceived by the participants which is in contrast to the study in Egypt where only

218 Discrimination-free Care was perceived to be high and other dimensions to be moderate [12].

219 The reason for high rating of Abuse-free Care in this study could be normalization of the abuse

220 in the health care setting [14], where delivering women think that it is normal to be abused

221 physically and/or verbally for better labor outcomes. Also, despite the knowledge of principles of

222 RMC among health care providers, this knowledge may not translate to an improvement in

223 actual respectful care at the bedside [14].

224 Most of the women $(91.3 \%)$ perceived that they were treated in a friendly manner which is

225 consistent with a direct observation of RMC in health facilities of five countries in East and

226 Southern Africa (86\%) [7]. Talking positively about the pain and relief measures was one of the

227 components of Friendly Care where very few respondents (2.0\%) disagreed with the statement.

228 The reasons for not addressing pain may be due to the lack of availability of a doctor [14] and/or

229 the shortage of health workers persistent in the country [15]. The shortage, however, might have

230 been more pronounced at the time of data collection due to the ongoing staff adjustment process

231 undertaken as part of implementing Federalism in the country [16].

232 WHO recommends communication between maternity care providers and women in labor, using

233 simple and culturally acceptable methods [17]. Evidence suggests that language barrier is a

234 critical factor that hinders effective communication and can also pose considerable risk to patient

235 safety and quality of care [18]. More than two third of the participants (84\%) in this study

236 confirmed that the health worker spoke in a language understandable to them. A study conducted 
medRxiv preprint doi: https://doi.org/10.1101/2021.01.23.21250363; this version posted January 27, 2021. The copyright holder for this preprint (which was not certified by peer review) is the author/funder, who has granted medRxiv a license to display the preprint in perpetuity.

It is made available under a CC-BY-NC-ND 4.0 International license .

237 in Egypt found that nearly $61 \%$ of the health workers did not communicate in an understandable

238 language. This suggests that language barrier was less common in our context. To ensure

239 respectful attitude and supportive environment during delivery, it is required to continue

240 emphasizing the importance of health care provider-client communication and client-centered

241 care [19].

242 One of the critical elements affecting patients' perception of RMC is the way in which a patient

243 is addressed by a name of her/his preference. Patients' preferred mode of address by healthcare

244 workers, to large extent, is influenced by ethnic and cultural factors. For instance, a study on

245 non-English speaking Australians shows that patients preferred to be called by their informal

246 name [20]. On the other hand, patients in countries like Iran [21] and Israel [22] preferred formal

247 address by title and surname. In this study, $47.2 \%$ respondents agreed that they were called by

248 their preferred name, which is similar to the study from Egypt [12]. However, with limited

249 evidence on Nepalese patients' preference of address by healthcare workers, the present study is

250 unable to provide contextual interpretation of the figure. Therefore, we recommend further study

251 on Nepalese patients' preferred mode of address by healthcare workers.

252 Neglect or abandonment during labor and delivery has been reported in varying degrees in

253 countries like Kenya (14.3\%) [23] and Tanzania (3.45\%)[24]. This neglect could be in form of

254 health workers not being present at the time of birth, not providing medications or not

255 communicating the progress of labor. More than a quarter of women in this study responded that

256 the health workers did not respond to their need whether or not asked, which is quite a large

257 figure compared to those reported previously. The reason for not responding to needs could be

258 the heavy workload of midwives and health care workers[25]. In an overburdened Nepali health

259 care system where patient to healthcare workers ratio is unimaginably high [26]. In a 
medRxiv preprint doi: https://doi.org/10.1101/2021.01.23.21250363; this version posted January 27, 2021. The copyright holder for this preprint (which was not certified by peer review) is the author/funder, who has granted medRxiv a license to display the preprint in perpetuity.

It is made available under a CC-BY-NC-ND 4.0 International license .

260

261

262

263

264

265

266

267

268

269

270

271

272

273

274

275

276

277

278

279

280

281

282

communication with Shanti Kandel, RN (January 2021), six thousand delivery in Bheri Hospital is attended by a group of only eleven staffs for the fiscal year $2076 / 77$. Silence can be a way in which a system defends itself against the many needs of patients. Silence from a care provider can cause neglect, resulting to avoidable complications during delivery [25], negative impact on the health of mother and / or baby [27] and also unwillingness to return or recommend others to the health facility for next delivery [28]. Respondents with complications are generally more likely to report D \& A during delivery[29]. Although a third of respondents in this study had complications, rates of D \& A remained low.

Women, during the process of delivery, are vulnerable to being abused by health workers whether it might be physical or verbal $[28,30,31]$. Such abuses are likely to result in a high rate of traumatic birth experience for women [32]. Different forms of abuse like being slapped (5.6\%) or being shouted at $(4.6 \%)$ has been reported in this study. Women experiencing physical and verbal abuse was found to be dramatically higher in another study conducted in central Nepal, which reported physical and verbal abuse to be $18.7 \%$ and $30 \%$ respectively [33]. The difference in reported abuse thus requires extensive research to identify the prevalence and institute appropriate interventions. A study has demonstrated that midwives feel a strong sense of accountability and responsibility for labor and delivery outcomes and tend to do whatever it takes to deliver a live baby to a healthy mother [34]. In addition, the midwives/ nurses ratio per population for Nepal is lesser (31.08/10,000 population) than the recommended by WHO (40/10,000 population) leading to overburden for health workers [35]. WHO recognizes that D \& A not only violate the rights of women to respectful care, but also threaten their rights to life, health, bodily integrity and freedom from discrimination [36]. However, abuse in any form, whether it be physical or verbal should never be tolerated during labor and delivery. 
medRxiv preprint doi: https://doi.org/10.1101/2021.01.23.21250363; this version posted January 27, 2021. The copyright holder for this preprint (which was not certified by peer review) is the author/funder, who has granted medRxiv a license to display the preprint in perpetuity.

It is made available under a CC-BY-NC-ND 4.0 International license .

283 Nearly half of the respondents (48.3\%) agreed that they were kept waiting for a long time,

284 which is substantially higher than the study conducted in Ghana, Guinea, Myanmar, and Nigeria

285 where $22 \%$ reported waiting for long periods before being attended by health workers [4]. The

286 delay in care $(27.8 \%)$ might be due to too few staff as compared to patients as revealed by a

287 study of midwives of Malawi [8]. The situation might be similar in Nepal as shortage of staffs in

288 the hospital setting has been reported [37], further worsened by the ongoing shifts in staff

289 allocation as a part of Federalism.

290 Few participants i.e. approximately three out of a hundred, agreed that the health workers did not

291 treat them well because of personal or their companions' attributes, which is in contrast to a

292 study conducted in Nigeria that showed a higher percentage of discrimination faced by

293 respondents at $8.1 \%$ [38]. Birth preparedness practice in Nepal tends to be higher as reported by

294 a study that denotes familiarization of pregnant women with the delivery setting. Early

295 communication and interpersonal relationship between care provider and patient could be a cause

296 for higher Discrimination-free Care [39].

297 Women with SVD were two times more likely to have a neutral response about RMC for Timely

298 Care as compared to those who had cesarean delivery. Women experiencing caesarian delivery

299 could have ultimately perceived the urgency of services for delivering a healthy baby, thus

300 women with SVD would be more likely to report neutral Timely Care. Similarly, those who earn

301 less than twenty thousand Nepalese Rupees were twice as likely to feel they had a high level of

302 timely RMC. Women of lower economic status may be more tolerant of a long wait in order to

303 receive care in a government facility with higher case load as opposed to delivering at home. 


\section{Limitations}

305 This study has used a standardized tool to gather quantitative information about D \& A faced by

307 perceptions and/or those of delivering women could not be obtained. Also, the potential for generalization of the findings cannot be ascertained as only a single tertiary care center in western Nepal has been included for the study.

Information bias and courtesy bias might have occurred as the information was collected by an

311 on- duty student nurse, although the respondents were assured prior to the study that their

312 opinion would have no impact on further treatment.

\section{Recommendations}

314 Any forms of D \& A must be prohibited during labor and delivery so that women can enjoy their 315 experience of labor and delivery. Irrespective of the health system or staff-related issues; timely 316 care must be of priority in order to ensure quality maternity care. Timely Care is simply not 317 always possible in highly constrained settings such as Bheri Hospital, but the perception of

318 Timely Care might possibly be reduced by additional communication and explanations of the 319 cause of the delay.

320 Further studies should be conducted to determine RMC at all levels of the healthcare system 321 throughout the country, such that potential generalization of our findings and appropriate 322 interventions for improvement can be planned accordingly.

323 Sustained interaction with the health system are required to implement behavior change

324 intervention central to promoting respectful care [40]. The successful improvement in maternity 325 care environment for women and midwives needs broader interdisciplinary perspectives on the 326 wider drivers of midwives' disrespectful attitudes and behaviors [8]. 


\section{Conclusion}

328 This study concludes that RMC is practiced highly in western Nepal in terms of Friendly Care,

329 Abuse-free Care, and Discrimination-free Care. However, Timely Care is less reported.

330 Therefore, appropriate interventions to provide Timely Care to delivering women must be

331 instituted. Along with this, adequate communication and explanation of delay can reduce

332 perception of delayed care among care recipients. Physical or verbal abuse during labor and

333 delivery must not be tolerated, and while rates of abuse were shown to be low in this study, there

334 remains room for improvement. Further research on RMC in Nepal is required to clarify the

335 drivers for D \& A and examine potential solutions.

\section{Abbreviations}

337 D\&A- Disrespect \& Abuse

338 LSCS - Lower Segment Caesarion Section

339 MMR - Maternal Mortality Ratio

340 NHRC- Nepal Health Research Council

341 RMC- Respectful Maternity Care

342 SDG - Sustainable Development Goals

343 SVD - Spontaneous Vaginal Delivery

344 WHO- World Health Organization

345 Declaration 
Competing interests: The authors declare no competing interests.

347 Funding: The study was self-funded by the authors.

348 Acknowledgments: The authors are immensely thankful to the management of Bheri

349 Hospital and to the NHRC for ethical approval. We express sincere gratitude to all women who 350 participated in this study along with delivery room residents and midwives for providing support

351 during the study. At last but not the least, we are thankful to all the student nurses of Sushma

352 Koirala Memorial Hospital, Nepalgunj, Banke for their support during data collection.

353 References

354 [1] Aryal KK, Sharma SK, Khanal MN, et al. Maternal health care in Nepal: Trends and determinants [Internet]. 2019. Available from: https://dhsprogram.com/pubs/pdf/FA118/FA118.pdf.

NHRC. Accelerating the safe motherhood program to avert preventable maternal deaths in Nepal [Internet]. Kathmandu; 2016. Available from: http://nhrc.gov.np/wpcontent/uploads/2019/07/Policy-Brief-on-Maternal-Mortality-in-Nepal.pdf. in maternal mortality between 1990 and 2015 with scenario-based projections to 2030: a systematic analysis by the United Nations Maternal Mortality Estimation Inter-Agency Group. Lancet [Internet]. 2016;387:462-474. Available from: https://www.ncbi.nlm.nih.gov/pmc/articles/PMC5515236/pdf/nihms863926.pdf. 
medRxiv preprint doi: https://doi.org/10.1101/2021.01.23.21250363; this version posted January 27, 2021. The copyright holder for this preprint (which was not certified by peer review) is the author/funder, who has granted medRxiv a license to display the preprint in perpetuity.

It is made available under a CC-BY-NC-ND 4.0 International license .

365

366

367

368

369

370

371

372

373

374

375

376

377

378

379

[4] Bohren MA, Mehrtash H, Fawole B, et al. How women are treated during facility-based childbirth in four countries $\square$ : a cross-sectional study with labour observations and community-based surveys. Lancet [Internet]. 2019;394:1750-1763. Available from: https://www.thelancet.com/journals/lancet/article/PIIS0140-6736(19)31992-0/fulltext.

[5] Kruk ME, Kujawski S, Mbaruku G, et al. Disrespectful and abusive treatment during facility delivery in Tanzania $\square$ : a facility and community survey. Health Policy Plan [Internet]. 2018;33:e26-e33. Available from: https://academic.oup.com/heapol/article/33/1/e26/2907853.

[6] Afulani PA, Phillips B, Aborigo RA, et al. Person-centred maternity care in low-income and middle-income countries_analysis of data from Kenya, Ghana, and India. Lancet Glob Heal [Internet]. 2019;7:e96-109. Available from: https://www.sciencedirect.com/science/article/pii/S2214109X18304030.

[7] Rosen HE, Lynam PF, Carr C, et al. Direct observation of respectful maternity care in five countries $\square$ : a cross-sectional study of health facilities in East and Southern Africa. BMC Pregnancy Childbirth [Internet]. 2015;15:1-11. Available from: https://europepmc.org/article/PMC/4657214.

[8] Bradley S, Chipeta E, Kamwendo F, et al. Too few staff , too many patients $\square$ : a qualitative study of the impact on obstetric care providers and on quality of care in Malawi. BMC Pregnancy Childbirth [Internet]. 2015;15:1-10. Available from: https://www.ncbi.nlm.nih.gov/pubmed/25880644.

[9] WHO Reproductive Health Library. WHO recommendation on respectful maternity care during labour and childbirth [Internet]. WHO Reprod. Heal. Libr. Geneva World Heal. 
Organ. 2018. p. 1-11. Available from: https://extranet.who.int/rhl/topics/preconceptionpregnancy-childbirth-and-postpartum-care/care-during-childbirth/who-recommendationrespectful-maternity-care-during-labour-and-childbirth.

[10] USAID. Respectful maternity care [Internet]. 2012. Available from: https://toolkits.knowledgesuccess.org/sites/default/files/rmc_survey_report_0_0.pdf.

[11] Thapa K, Parajuli U. Trend of caesarean section in Bheri zonal hospital. J NepalgunjMedical Coll Coll [Internet]. 2018;16:41-45. Available from: https://www.nepjol.info/index.php/JNGMC/article/view/24227?fbclid=IwAR1wEsxQkw OsBNcWF13t1P0Mhyt4CuRu0MeFCLMnn7FKLm2BRpRxhOtz9pI.

[12] Mousa O, Turingan OM. Quality of care in the delivery room $\square$ : Focusing on respectful maternal care practices. J Nurs Educ Pract [Internet]. 2019;9. Available from: http://www.sciedupress.com/journal/index.php/jnep/article/view/13634.

[13] Sheferaw ED, Mengesha TZ, Wase SB. Development of a tool to measure women' s perception of respectful maternity care in public health facilities. BMC Pregnancy Childbirth [Internet]. 2016;16:1-8. Available from: http://dx.doi.org/10.1186/s12884-0160848-5.

[14] Lambert J, Etsane E, Bergh A. ' I thought they were going to handle me like a queen but they didn ' t': A qualitative study exploring the quality of care provided to women at the time of birth '. Midwifery [Internet]. 2018;62:256-263. Available from: https://doi.org/10.1016/j.midw.2018.04.007. Nepal Heal Res Counc [Internet]. 2013;11:126-132. Available from: 
https://pubmed.ncbi.nlm.nih.gov/24362599/.

410

[16] Poudel A. Staff adjustment affects health services across the country. Kathmandu Post [Internet]. 2019 Dec 3; Available from: https://kathmandupost.com/health/2019/12/03/staff-adjustment-affects-health-servicesacross-the-country.

[17] WHO. WHO recommendation on effective communication between maternity care providers and women in labour. Reprod. Heal. Libr. Geneva; 2018.

[18] Moissac D De, Bowen S. Impact of language barriers on quality of care and patient safety for official language minority francophones in Canada. J Patient Exp [Internet]. 2019;6:24-32. Available from: https://journals.sagepub.com/doi/full/10.1177/2374373518769008.

[19] Solomon S, Mark S, Merijn G, et al. Why do women prefer home births in Ethiopia? BMC Pregnancy Childbirth [Internet]. 2013;13. Available from: http://ovidsp.ovid.com/ovidweb.cgi?T=JS\&PAGE=reference $\& D=$ medl $\& N E W S=N \& A N=$ 23324550.

[20] Parsons SR, Hughes AJ, Friedman ND. "Please don't call me Mister": Patient preferences of how they are addressed and their knowledge of their treating medical team in an Australian hospital. BMJ Open [Internet]. 2016;6:1-4. Available from: https://pubmed.ncbi.nlm.nih.gov/26739720/.

[21] Najafi M, Khoshdel A, Kheiri S. Preferences of Iranian patients about style of labelling and calling of their physicians. J Pakistan Med Assoc [Internet]. 2012;62:668-671. Available from: https://jpma.org.pk/article-details/3549. 
medRxiv preprint doi: https://doi.org/10.1101/2021.01.23.21250363; this version posted January 27, 2021. The copyright holder for this preprint (which was not certified by peer review) is the author/funder, who has granted medRxiv a license to display the preprint in perpetuity.

It is made available under a CC-BY-NC-ND 4.0 International license .

431 [22] Dekeyser FG, Wruble IAW, Margalith II. Patients voice issues of dress and address.

432

433

434

435

436

437

438

439

440

441

442

443

444

445

446

447

448

449

450

451

452

Holist Nurs Pract [Internet]. 2003;17:290-294. Available from:

https://journals.lww.com/hnpjournal/Abstract/2003/11000/Patients_Voice_Issues_of_Dres s_and_Address.3.aspx.

[23] Abuya T, Warren CE, Miller N, et al. Exploring the prevalence of disrespect and abuse during childbirth in Kenya. PLoS One [Internet]. 2015;10:1-13. Available from: http://dx.doi.org/10.1371/journal.pone.0123606.

[24] Freedman LP, Kujawski SA, Mbuyita S, et al. Eye of the beholder $\square$ ? Observation versus self- report in the measurement of disrespect and abuse during facility-based childbirth. Reprod Health Matters [Internet]. 2018;26:107-122. Available from: https://www.tandfonline.com/doi/full/10.1080/09688080.2018.1502024.

[25] Bradley S, Chipeta E, Kamwendo F, et al. Too few staff , too many patients $\square$ : a qualitative study of the impact on obstetric care providers and on quality of care in Malawi. BMC Pregnancy Childbirth [Internet]. 2015;15. Available from: https://www.ncbi.nlm.nih.gov/pubmed/25880644.

[26] Caffrey M, Chilvers R, Martineau T. Human resources for health Nepal country profile [Internet]. 2013. Available from:

http://www.nhssp.org.np/NHSSP_Archives/human_resources/HRH_Nepal_profile_august 2013.pdf.

[27] Lappeman M, Swartz L. Rethinking obstetric violence and the "neglect of neglect": the silence of a labour ward milieu in a South African district hospital. BMC Int Health Hum Rights [Internet]. 2019;19:30. Available from: 
medRxiv preprint doi: https://doi.org/10.1101/2021.01.23.21250363; this version posted January 27, 2021. The copyright holder for this preprint (which was not certified by peer review) is the author/funder, who has granted medRxiv a license to display the preprint in perpetuity.

It is made available under a CC-BY-NC-ND 4.0 International license .

https://bmcinthealthhumrights.biomedcentral.com/articles/10.1186/s12914-019-0218-2.

454

455

456

457

458

459

460

461

462

463

464

465

466

467

468

469

470

471

472

473

474

[28] D'Ambruoso L, Abbey M, Hussein J. Please understand when I cry out in pain: Women's accounts of maternity services during labour and delivery in Ghana. BMC Public Health [Internet]. 2005;5:1-11. Available from: https://link.springer.com/content/pdf/10.1186/1471-2458-5-140.pdf.

[29] Wassihun B, Zeleke S. Compassionate and respectful maternity care during facility based child birth and women' s intent to use maternity service in Bahir Dar, Ethiopia. BMC Pregnancy Childbirth [Internet]. 2018;18:1-9. Available from: https://bmcpregnancychildbirth.biomedcentral.com/articles/10.1186/s12884-018-19098\#: :text=Respondents who were facing complication during labor and,did not face complications \%5BAOR $\square \% 3 \mathrm{D} \square 2.38 \% 2895 \% 25 \mathrm{CI} \% 3 \mathrm{~B} 1.28 \% 2 \mathrm{C} 4.45 \% 29 \% 5 \mathrm{D}$.

[30] Sando D, Ratcliffe H, Mcdonald K, et al. The prevalence of disrespect and abuse during facility-based childbirth in urban Tanzania. BMC Pregnancy Childbirth [Internet]. 2016;16. Available from: http://dx.doi.org/10.1186/s12884-016-1019-4.

[31] Orpin J, Puthussery S, Davidson R, et al. Women's experiences of disrespect and abuse in maternity care facilities in Benue State, Nigeria. BMC Pregnancy Childbirth [Internet]. 2018 [cited 2019 Sep 27];18:1-9. Available from: https://bmcpregnancychildbirth.biomedcentral.com/articles/10.1186/s12884-018-1847-5.

[32] Hodges S. Abuse in hospital-based birth settings? J Perinat Educ [Internet]. 2009;18:8-11. Available from: https://www.ncbi.nlm.nih.gov/pmc/articles/PMC2776520/.

[33] Pathak P, Ghimire B. Perception of women regarding respectful maternity care during facility-based childbirth. Obstet Gynecol Int. 2020;2020. 
[34] Yakubu J, Health C, Initiative A, et al. It 's for the greater good $\square$ : Perspectives on maltreatment during labor and delivery in Rural Ghana. J Obstet Gynecol [Internet]. 2014;4:383-390. Available from: https://www.scirp.org/journal/paperinformation. aspx ?paperid=46320.

[35] WHO. Nursing and midwifery personnel (per 10000 population). 2018.

[36] United Nations. A human rights-based approach to mistreatment and violence against women in reproductive health services with a focus on childbirth and obstetric violence [Internet]. Geneva; 2019. Available from: https://digitallibrary.un.org/record/3823698?ln=en.

[37] Thapa K, Clark RB. Helping babies breathe ( HBB ) program for reduction of neonatal mortality $\square$ : A hospital based cost effective intervention in Nepal. Med J Shree Birendra Hosp [Internet]. 2020; Available from: https://www.nepjol.info/index.php/MJSBH/article/view/25961.

[38] Ijadunola MY, Olotu EA, Oyedun OO, et al. Lifting the veil on disrespect and abuse in facility-based child birth care $\square$ : findings from South West Nigeria. BMC Pregnancy Childbirth [Internet]. 2019;19:1-8. Available from: https://bmcpregnancychildbirth.biomedcentral.com/articles/10.1186/s12884-019-2188-8.

[39] Silwal K, Poudyal JK, Shah R, et al. Factors influencing birth preparedness in Rapti Municipality of Chitwan, Nepal. Int J Pediatr [Internet]. 2020;2020. Available from: https://www.hindawi.com/journals/ijpedi/2020/7402163/.

[40] Ndwiga C, Warren CE, Ritter J, et al. Exploring provider perspectives on respectful maternity care in Kenya $\square$ : “Work with what you have ." Reprod Health [Internet]. 
medRxiv preprint doi: https://doi.org/10.1101/2021.01.23.21250363; this version posted January 27, 2021. The copyright holder for this preprint (which was not certified by peer review) is the author/funder, who has granted medRxiv a license to display the preprint in perpetuity.

It is made available under a CC-BY-NC-ND 4.0 International license .

2017;14:1-13. Available from: https://reproductive-health-

journal.biomedcentral.com/articles/10.1186/s12978-017-0364-8.

Table 1. Distribution of variables in the study

Part I- Socio-demographic characteristics and obstetric history
Demographic Information: Age of Mother, Ethnicity, Religion, Type of Family, Educational Status, Educational Level, Occupation, Spouse's Educational Status, and Spouse's Occupation

Obstetric History: Gravida, Para, Week of Gestation, Type of Delivery, and Complication During Labor

Friendly Care, Abuse-free Care, Timely Care, and Discrimination-free Care
Part II- Perceived Disrespect \& Abuse ${ }^{12}$

Table 2. Distribution of participants according to socio-demographic information $(n=445)$

\begin{tabular}{|l|l|l|}
\hline Characteristics & Frequency (n) & Percent (\%) \\
\hline Age (Years) & & \\
\hline$<\mathbf{2 0}$ & 88 & 19.8 \\
$\mathbf{2 0 - 3 0}$ & 331 & 74.4 \\
$\mathbf{3 0 - 4 0}$ & 26 & 5.8 \\
\hline Ethnicity & & \\
\hline Brahmin/Chhetri & 136 & 30.6 \\
Janjati & 205 & 46.1 \\
Madhesi/Dalit and others & 104 & 23.4 \\
\hline Religion & & \\
\hline Hindu & 406 & 91.2 \\
Others & 39 & 8.8 \\
\hline
\end{tabular}




\begin{tabular}{|c|c|c|}
\hline \multicolumn{3}{|l|}{ Educational Status } \\
\hline Educated & 386 & 86.7 \\
\hline Uneducated & 59 & 13.3 \\
\hline \multicolumn{3}{|l|}{ Occupation } \\
\hline Unemployed & 226 & 50.8 \\
\hline Employed & 219 & 49.2 \\
\hline \multicolumn{3}{|l|}{ Family type } \\
\hline Nuclear & 208 & 46.7 \\
\hline Joint\& Extended & 237 & 53.3 \\
\hline \multicolumn{3}{|l|}{ Monthly income } \\
\hline$<=20000$ & 263 & 59.1 \\
\hline$>20000$ & 182 & 40.9 \\
\hline \multicolumn{3}{|l|}{ Spouse's educational status } \\
\hline Educated & 408 & 91.7 \\
\hline Uneducated & 37 & 8.3 \\
\hline \multicolumn{3}{|l|}{ Spouse's Occupation } \\
\hline Foreign employment & 25 & 5.6 \\
\hline Non-formal employment & 318 & 71.5 \\
\hline Formal employment & 102 & 22.9 \\
\hline
\end{tabular}

506 Table 3. Distribution of participants according to obstetric history $(n=445)$

\begin{tabular}{|l|l|l|}
\hline Characteristics & Frequency (n) & Percent (\%) \\
\hline Gravida & & \\
\hline$<=2$ & 337 & 75.7 \\
\hline Para & 108 & 24.3 \\
\hline Primi para & & \\
Multipara & 157 & 35.3 \\
\hline
\end{tabular}




\begin{tabular}{|l|l|l|}
\hline Week of gestation & & \\
\hline Preterm & 19 & 4.3 \\
Term & 426 & 95.7 \\
\hline Type of delivery & & \\
\hline Spontaneous vaginal delivery & 229 & 51.5 \\
Augmented & 63 & 14.2 \\
Lower section cesarean section & 153 & 34.4 \\
\hline Complications during labor & & \\
\hline Yes & 148 & 33.3 \\
\hline No & 148 & 66.7 \\
\hline
\end{tabular}

Table 4 Participant reports of RMC ( $=445)$

\begin{tabular}{|c|c|c|c|c|c|c|c|}
\hline Components of RMC & $\begin{array}{l}\text { SD } \\
\mathbf{f}(\%)\end{array}$ & $\begin{array}{l}\mathrm{D} \\
\mathrm{f}(\%)\end{array}$ & $\begin{array}{l}\mathbf{N} \\
\mathbf{f}(\%)\end{array}$ & $\begin{array}{l}\text { A } \\
\mathbf{f}(\%)\end{array}$ & $\begin{array}{l}\text { SA } \\
\mathbf{f}(\%)\end{array}$ & $\begin{array}{l}\text { Mean } \\
\text { (SE) }\end{array}$ & $\begin{array}{l}\text { CM } \\
(\mathrm{SE})\end{array}$ \\
\hline \multicolumn{8}{|l|}{$\begin{array}{l}\text { Friendly care: The health } \\
\text { worker/s }\end{array}$} \\
\hline Cared with a kind approach & $\begin{array}{l}3 \\
(0.7)\end{array}$ & $\begin{array}{l}1 \\
(0.2)\end{array}$ & $\begin{array}{l}1 \\
(0.2)\end{array}$ & $\begin{array}{l}141 \\
(31.7)\end{array}$ & $\begin{array}{l}299 \\
(67.2)\end{array}$ & $\begin{array}{l}4.64 \\
(.027)\end{array}$ & \multirow[t]{6}{*}{$\begin{array}{l}4.42 \\
(.028)\end{array}$} \\
\hline Treated in a friendly manner & $\begin{array}{l}10 \\
(2.2)\end{array}$ & $\begin{array}{l}2 \\
(0.4)\end{array}$ & $\begin{array}{l}27 \\
(6.1)\end{array}$ & $\begin{array}{l}185 \\
(41.6)\end{array}$ & $\begin{array}{l}221 \\
(49.7)\end{array}$ & $\begin{array}{l}4.36 \\
(.038)\end{array}$ & \\
\hline $\begin{array}{l}\text { Talked positively about pain } \\
\text { and relief }\end{array}$ & $\begin{array}{l}5 \\
(1.1)\end{array}$ & $\begin{array}{l}4 \\
(0.9)\end{array}$ & $\begin{array}{l}14 \\
(3.1)\end{array}$ & $\begin{array}{l}200 \\
(44.9)\end{array}$ & $\begin{array}{l}222 \\
(49.9)\end{array}$ & $\begin{array}{l}4.42 \\
(.033)\end{array}$ & \\
\hline $\begin{array}{l}\text { Showed his/her concern and } \\
\text { empathy }\end{array}$ & - & $\begin{array}{l}1 \\
(0.2)\end{array}$ & $\begin{array}{l}38 \\
(8.5)\end{array}$ & $\begin{array}{l}187 \\
(42)\end{array}$ & $\begin{array}{l}219 \\
(49.2)\end{array}$ & $\begin{array}{l}4.40 \\
(.031)\end{array}$ & \\
\hline $\begin{array}{l}\text { Treated with respect as an } \\
\text { individual }\end{array}$ & $\begin{array}{l}1 \\
(0.2)\end{array}$ & $\begin{array}{l}6 \\
(1.3)\end{array}$ & $\begin{array}{l}66 \\
(14.8)\end{array}$ & $\begin{array}{l}181 \\
(40.7)\end{array}$ & $\begin{array}{l}191 \\
(42.9)\end{array}$ & $\begin{array}{l}4.25 \\
(.036)\end{array}$ & \\
\hline $\begin{array}{l}\text { Spoke in a language that } I \\
\text { could understand }\end{array}$ & $\begin{array}{l}18 \\
(4)\end{array}$ & $\begin{array}{l}29 \\
(6.5)\end{array}$ & $\begin{array}{l}24 \\
(5.4)\end{array}$ & $\begin{array}{l}174 \\
(39.1)\end{array}$ & $\begin{array}{l}200 \\
(44.9)\end{array}$ & $\begin{array}{l}4.14 \\
(.05)\end{array}$ & \\
\hline
\end{tabular}


medRxiv preprint doi: https://doi.org/10.1101/2021.01.23.21250363; this version posted January 27, 2021. The copyright holder for this preprint (which was not certified by peer review) is the author/funder, who has granted medRxiv a license to display the preprint in perpetuity.

It is made available under a CC-BY-NC-ND 4.0 International license .

\begin{tabular}{|c|c|c|c|c|c|c|c|}
\hline Called me by my name & $\begin{array}{l}113 \\
(25.4)\end{array}$ & $\begin{array}{l}97 \\
(21.8)\end{array}$ & $\begin{array}{l}46 \\
(10.3)\end{array}$ & $\begin{array}{l}130 \\
(29.2)\end{array}$ & $\begin{array}{l}59 \\
(13.3)\end{array}$ & $\begin{array}{l}2.83 \\
(.068)\end{array}$ & \\
\hline \multicolumn{8}{|l|}{$\begin{array}{l}\text { Abuse free care: } \\
\text { The health worker/s }\end{array}$} \\
\hline $\begin{array}{l}\text { Responded to my needs } \\
\text { whether or not I asked }\end{array}$ & $\begin{array}{l}51 \\
(11.5)\end{array}$ & $\begin{array}{l}94 \\
(21.1)\end{array}$ & $\begin{array}{l}89 \\
(20.0)\end{array}$ & $\begin{array}{l}90 \\
(20.2)\end{array}$ & $\begin{array}{l}121 \\
(27.2)\end{array}$ & $\begin{array}{l}3.31 \\
(.065)\end{array}$ & $\begin{array}{l}4.29 \\
(.044)\end{array}$ \\
\hline $\begin{array}{l}\text { Slapped me during delivery } \\
\text { for different reasons }(R)\end{array}$ & $\begin{array}{l}267 \\
(60.0)\end{array}$ & $\begin{array}{l}121 \\
(27.2)\end{array}$ & $\begin{array}{l}32 \\
(7.2)\end{array}$ & $\begin{array}{l}19 \\
(4.3)\end{array}$ & $\begin{array}{l}6 \\
(1.3)\end{array}$ & $\begin{array}{l}4.40 \\
(0.43)\end{array}$ & \\
\hline $\begin{array}{l}\text { Shouted at me because I } \\
\text { hadn't done what I was told } \\
\text { to do }(R)\end{array}$ & $\begin{array}{l}249 \\
(56.0)\end{array}$ & $\begin{array}{l}125 \\
(28.1)\end{array}$ & $\begin{array}{l}50 \\
(11.2)\end{array}$ & $\begin{array}{l}17 \\
(3.8)\end{array}$ & $\begin{array}{l}4 \\
(0.9)\end{array}$ & $\begin{array}{l}4.34 \\
(.042)\end{array}$ & \\
\hline \multicolumn{8}{|l|}{ Timely Care } \\
\hline $\begin{array}{l}\text { Kept waiting for a long time } \\
\text { before receiving service (r) }\end{array}$ & $\begin{array}{l}98 \\
(22.0)\end{array}$ & $\begin{array}{l}117 \\
(26.3)\end{array}$ & $\begin{array}{l}106 \\
(23.8)\end{array}$ & $\begin{array}{l}78 \\
(17.5)\end{array}$ & $\begin{array}{l}46 \\
(10.3)\end{array}$ & $\begin{array}{l}3.32 \\
(.061)\end{array}$ & $\begin{array}{l}3.10 \\
(.057)\end{array}$ \\
\hline $\begin{array}{l}\text { Allowed to practice cultural } \\
\text { rituals in the facility }\end{array}$ & $\begin{array}{l}169 \\
(38.0)\end{array}$ & $\begin{array}{l}107 \\
(24.0)\end{array}$ & $\begin{array}{l}87 \\
(19.6)\end{array}$ & $\begin{array}{l}19 \\
(4.3)\end{array}$ & $\begin{array}{l}63 \\
(14.2)\end{array}$ & $\begin{array}{l}2.33 \\
(.066)\end{array}$ & \\
\hline $\begin{array}{l}\text { Service provision was delayed } \\
\text { due to the health facility's } \\
\text { internal problems }(r)\end{array}$ & $\begin{array}{l}172 \\
(38.7)\end{array}$ & $\begin{array}{l}102 \\
(22.9)\end{array}$ & $\begin{array}{l}88 \\
(19.8)\end{array}$ & $\begin{array}{l}51 \\
(11.5)\end{array}$ & $\begin{array}{l}32 \\
(7.2)\end{array}$ & $\begin{array}{l}3.74 \\
(.060)\end{array}$ & \\
\hline \multicolumn{8}{|c|}{ Discrimination- free care: Some of the health workers } \\
\hline $\begin{array}{l}\text { Did not treat me well because } \\
\text { of my personal attributes }(R)\end{array}$ & $\begin{array}{l}330 \\
(74.2)\end{array}$ & $\begin{array}{l}89 \\
(20.0)\end{array}$ & $\begin{array}{l}11 \\
(2.5)\end{array}$ & $\begin{array}{l}9 \\
(2.0)\end{array}$ & $\begin{array}{l}6 \\
(1.3)\end{array}$ & $\begin{array}{l}4.64 \\
(.036)\end{array}$ & \multirow[t]{2}{*}{$\begin{array}{l}4.67 \\
(.032)\end{array}$} \\
\hline $\begin{array}{l}\text { Insulted me and my } \\
\text { companions due to } \mathrm{my} \\
\text { personal attributes }(\mathrm{R})\end{array}$ & $\begin{array}{l}316 \\
(71.0)\end{array}$ & $\begin{array}{l}112 \\
(25.2)\end{array}$ & $\begin{array}{l}4 \\
(0.9)\end{array}$ & $\begin{array}{l}5 \\
(1.1)\end{array}$ & $\begin{array}{l}8 \\
(1.8)\end{array}$ & $\begin{array}{l}4.62 \\
(.035)\end{array}$ & \\
\hline
\end{tabular}

SA-Strongly agree, A-Agree, $N$ - Neutral/ Indifferent, D-Disagree, SD-Strongly disagree

512 Table 5. Distribution of Friendly RMC by different socio-demographic and obstetric

513 characteristics $(n=445)$

\begin{tabular}{|l|c|c|c|c|l|}
\hline \multirow{2}{*}{ Characteristics } & \multicolumn{3}{|c|}{ Friendly care } & \multirow{2}{*}{$\begin{array}{l}\chi^{2} \\
\text { value }\end{array}$} \\
\cline { 2 - 5 } & $\begin{array}{c}\text { Moderate } \\
\text { RMC }\end{array}$ & High RMC & $\begin{array}{c}\text { Very high } \\
\text { RMC }\end{array}$ & value
\end{tabular}




\begin{tabular}{|c|c|c|c|c|c|}
\hline & $\mathbf{f}(\%)$ & $\mathbf{f}(\%)$ & $f(\%)$ & & \\
\hline \multicolumn{6}{|l|}{ Age } \\
\hline$<20$ & $1(1.1)$ & $41(46.6)$ & $46(52.3)$ & $8.958_{a}$ & .062 \\
\hline 20-30 & $24(7.3)$ & $149(45.0)$ & $158(47.7)$ & & \\
\hline $30-40$ & $1(3.8)$ & $16(61.5)$ & $9(34.6)$ & & \\
\hline \multicolumn{6}{|l|}{ Ethnicity } \\
\hline Brahmin/Chhetri & $10(7.4)$ & $58(42.6)$ & $68(50.0)$ & 6.754 & .149 \\
\hline Janjati & $8(3.9)$ & $92(44.9)$ & $105(51.2)$ & & \\
\hline Madhesi/Dalit \& others & $8(7.7)$ & $56(53.8)$ & $40(38.5)$ & & \\
\hline \multicolumn{6}{|l|}{ Educational Status } \\
\hline Educated & $25(6.5)$ & $177(45.9)$ & $184(47.7)$ & $2.817_{\mathrm{a}}$ & .244 \\
\hline Uneducated & $1(1.7)$ & $29(49.2)$ & $29(49.2)$ & & \\
\hline \multicolumn{6}{|l|}{ Occupation } \\
\hline Unemployed & $9(4.0)$ & $115(50.9)$ & $102(45.1)$ & 5.529 & .063 \\
\hline Employed & $17(7.8)$ & $91(416)$ & $111(50.7)$ & & \\
\hline \multicolumn{6}{|l|}{ Monthly income } \\
\hline$<=20000$ & $5(1.9)$ & $126(47.9)$ & $132(50.2)$ & 18.188 & .000 \\
\hline$>20000$ & $21(11.5)$ & $80(44.0)$ & $81(44.5)$ & & \\
\hline \multicolumn{6}{|l|}{ Spouse's Occupation } \\
\hline Foreign & $0(.0)$ & $13(52.0)$ & $12(48.0)$ & $3.605_{\mathrm{a}}$ & .462 \\
\hline Non-formal & $21(6.6)$ & $146(45.9)$ & $151(47.5)$ & & \\
\hline Formal employment & $5(4.9)$ & $47(46.1)$ & $50(49.0)$ & & \\
\hline \multicolumn{6}{|l|}{ Gravida } \\
\hline$<=2$ & $7(2.1)$ & $146(43.3)$ & $184(54.6)$ & 49.498 & .000 \\
\hline$>2$ & $19(17.6)$ & $60(55.6)$ & $29(26.9)$ & & \\
\hline \multicolumn{6}{|l|}{ Para } \\
\hline Primi para & $2(1.3)$ & $83(52.9)$ & $72(45.9)$ & 11.135 & .004 \\
\hline Multi para & $24(8.3)$ & $123(42.7)$ & $141(49.0)$ & & \\
\hline
\end{tabular}




\begin{tabular}{|l|l|l|l|l|l|}
\hline Week of gestation & & & & \\
\hline Preterm & 0 & $14(73.7)$ & $5(26.3)$ & $7.302_{\text {a }}$ & $\mathbf{. 0 2 6}$ \\
\hline Type of delivery & $26(6.1)$ & $192(45.1)$ & $208(48.8)$ & & \\
\hline SVD & & & & & \\
Augmented & $10(4.4)$ & $100(43.7)$ & $119(52.0)$ & $6.112_{\text {a }}$ & .191 \\
LSCS & $6(9.5)$ & $34(54.0)$ & $23(36.5)$ & & \\
\hline Complications & $10(6.5)$ & $72(47.1)$ & $71(46.4)$ & & \\
\hline Yes & & & & & \\
No & $7(4.7)$ & $69(46.6)$ & $72(48.6)$ & 0.504 & .777 \\
\hline
\end{tabular}

514 a - likelihood ratio

515

Table 6. Distribution of Abuse-free RMC by different socio-demographic and obstetric

517 characteristics $(n=445)$

\begin{tabular}{|c|c|c|c|c|c|c|c|}
\hline \multirow[t]{2}{*}{ Characteristics } & \multicolumn{5}{|c|}{ Abuse Free Care } & \multirow[t]{2}{*}{$\chi^{2}$} & \multirow{2}{*}{$\begin{array}{l}\text { p- } \\
\text { value }\end{array}$} \\
\hline & $\begin{array}{l}\text { Very } \\
\text { Low } \\
\text { RMC } \\
\text { f (\%) }\end{array}$ & $\begin{array}{l}\text { Low } \\
\text { RMC } \\
\text { f }(\%)\end{array}$ & $\begin{array}{l}\text { Moderate } \\
\text { RMC } \\
\text { f }(\%)\end{array}$ & $\begin{array}{l}\text { High } \\
\text { RMC } \\
\text { f }(\%)\end{array}$ & $\begin{array}{l}\text { Very } \\
\text { High } \\
\text { RMC } \\
\text { f (\%) }\end{array}$ & & \\
\hline \multicolumn{8}{|l|}{ Age } \\
\hline$<20$ & - & $2(2.3)$ & $13(14.8)$ & $39(44.3)$ & $34(38.6)$ & $11.606_{a}$ & \\
\hline $20-30$ & $4(1.2)$ & $12(3.6)$ & 71(21.5) & $94(28.4)$ & $150(45.3)$ & & .212 \\
\hline $30-40$ & - & $1(3.8)$ & $5(19.2)$ & $11(42.3)$ & $9(34.6)$ & & \\
\hline \multicolumn{8}{|l|}{ Ethnicity } \\
\hline Brahmin/Chhetri & $0(.0)$ & $2(1.5)$ & $32(23.5)$ & $42(30.9)$ & $60(44.1)$ & 11.214 & .186 \\
\hline Janjati & $1(.5)$ & $8(3.9)$ & $36(17.6)$ & $66(32.2)$ & 94(45.9) & & .190 \\
\hline $\begin{array}{l}\text { Madhesi/Dalit \& } \\
\text { others }\end{array}$ & $3(2.9)$ & $5(4.8)$ & $21(20.2)$ & $36(34.6)$ & $39(37.5)$ & & \\
\hline $\begin{array}{l}\text { Educational } \\
\text { Status }\end{array}$ & & & & & & & \\
\hline
\end{tabular}




\begin{tabular}{|c|c|c|c|c|c|c|c|}
\hline $\begin{array}{l}\text { Educated } \\
\text { Uneducated }\end{array}$ & $\begin{array}{l}3(.8) \\
1(1.7)\end{array}$ & $\begin{array}{l}10(2.6) \\
5(8.5)\end{array}$ & $\begin{array}{l}74(19.2) \\
15(25.4)\end{array}$ & $\begin{array}{l}129(33.4) \\
15(25.4)\end{array}$ & $\begin{array}{l}170(44.0) \\
23(39.0)\end{array}$ & $11.214_{\mathrm{a}}$ & .190 \\
\hline \multicolumn{8}{|l|}{ Occupation } \\
\hline $\begin{array}{l}\text { Unemployed } \\
\text { Employed }\end{array}$ & $\begin{array}{l}3(1.3) \\
1(.5)\end{array}$ & $\begin{array}{l}6(2.7) \\
9(4.1)\end{array}$ & $\begin{array}{l}40(17.7) \\
49(22.4)\end{array}$ & $\begin{array}{l}81(35.8) \\
63(28.8)\end{array}$ & $\begin{array}{l}96(42.5) \\
97(44.3)\end{array}$ & $4.713_{\mathrm{a}}$ & .318 \\
\hline \multicolumn{8}{|c|}{ Monthly income } \\
\hline $\begin{array}{l}<=20000 \\
>20000\end{array}$ & $\begin{array}{l}1(.4) \\
3(1.6)\end{array}$ & $\begin{array}{l}11(4.2) \\
4(2.2)\end{array}$ & $\begin{array}{l}50(19.0) \\
39(21.4)\end{array}$ & $\begin{array}{l}79(30.0) \\
65(35.7)\end{array}$ & $\begin{array}{l}122(46.4) \\
71(39.0)\end{array}$ & $5.981_{\mathrm{a}}$ & .201 \\
\hline \multicolumn{8}{|l|}{$\begin{array}{l}\text { Spouse's } \\
\text { Occupation }\end{array}$} \\
\hline $\begin{array}{l}\text { Foreign } \\
\text { Non-formal } \\
\text { Formal } \\
\text { employment }\end{array}$ & $\begin{array}{l}0(.0) \\
3(.9) \\
1(1.0)\end{array}$ & $\begin{array}{l}0(.0) \\
15(4.7) \\
0(.0)\end{array}$ & $\begin{array}{l}4(16.0) \\
61(19.2) \\
24(23.5)\end{array}$ & $\begin{array}{l}3(12.0) \\
99(31.1) \\
42(41.2)\end{array}$ & $\begin{array}{l}18(72.0) \\
140(44.0) \\
35(34.3)\end{array}$ & $24.143_{\mathrm{a}}$ & .002 \\
\hline \multicolumn{8}{|l|}{ Gravida } \\
\hline $\begin{array}{l}<=2 \\
>2\end{array}$ & $\begin{array}{l}2(.6 \%) \\
2(1.9)\end{array}$ & $\begin{array}{l}14(4.2) \\
1(.9)\end{array}$ & $\begin{array}{l}69(20.5) \\
20(18.5)\end{array}$ & $\begin{array}{l}103(30.6) \\
41(38.0)\end{array}$ & $\begin{array}{l}149(44.2) \\
44(40.7)\end{array}$ & $6.223_{\mathrm{a}}$ & .183 \\
\hline \multicolumn{8}{|l|}{ Para } \\
\hline $\begin{array}{l}\text { Primi para } \\
\text { Multipara }\end{array}$ & $\begin{array}{l}1(.6) \\
3(1.0)\end{array}$ & $\begin{array}{l}9(5.7) \\
6(2.1)\end{array}$ & $\begin{array}{l}40(25.5) \\
49(17.0)\end{array}$ & $\begin{array}{l}54(34.4) \\
90(31.2)\end{array}$ & $\begin{array}{l}53(33.8) \\
140(48.6)\end{array}$ & $13.184_{a}$ & .010 \\
\hline \multicolumn{8}{|c|}{ Week of gestation } \\
\hline $\begin{array}{l}\text { Preterm } \\
\text { Term }\end{array}$ & $\begin{array}{l}0(.0) \\
4(.9)\end{array}$ & $\begin{array}{l}0(.0) \\
15(3.5)\end{array}$ & $\begin{array}{l}7(36.8) \\
82(19.2)\end{array}$ & $\begin{array}{l}7(36.8) \\
137(32.2)\end{array}$ & $\begin{array}{l}5(26.3) \\
188(44.1)\end{array}$ & $5.592_{\mathrm{a}}$ & .232 \\
\hline \multicolumn{8}{|c|}{ Type of delivery } \\
\hline $\begin{array}{l}\text { SVD } \\
\text { Augmented } \\
\text { LSCS }\end{array}$ & $\begin{array}{l}3(1.3) \\
1(1.6) \\
0(.0)\end{array}$ & $\begin{array}{l}4(1.7) \\
9(14.3) \\
2(1.3)\end{array}$ & $\begin{array}{l}50(21.8) \\
12(19.0) \\
27(17.6)\end{array}$ & $\begin{array}{l}69(30.1) \\
25(39.7) \\
50(32.7)\end{array}$ & $\begin{array}{l}103(45.0) \\
16(25.4) \\
74(48.4)\end{array}$ & $29.030_{\mathrm{a}}$ & .000 \\
\hline \multicolumn{8}{|c|}{ Complications } \\
\hline Yes & $1(.7)$ & $1(.7)$ & $32(21.6)$ & $45(30.4)$ & $69(46.6)$ & $7.391_{\mathrm{a}}$ & .117 \\
\hline
\end{tabular}


99(33.3)

\section{4(41.8)}

a - likelihood ratio

519 Table 7. Distribution of Timely RMC by different socio-demographic and obstetric

520 characteristics $(n=445)$

\begin{tabular}{|c|c|c|c|c|c|c|c|}
\hline \multirow[t]{2}{*}{ Characteristics } & \multicolumn{5}{|c|}{ Timely Care } & \multirow[t]{2}{*}{$\chi^{2}$} & \multirow{2}{*}{$\begin{array}{l}\text { p- } \\
\text { value }\end{array}$} \\
\hline & $\begin{array}{l}\text { Very Low } \\
\text { RMC }\end{array}$ & $\begin{array}{l}\text { Low } \\
\text { RMC }\end{array}$ & $\begin{array}{l}\text { Moderate } \\
\text { RMC }\end{array}$ & $\begin{array}{l}\text { High } \\
\text { RMC }\end{array}$ & $\begin{array}{l}\text { Very high } \\
\text { RMC }\end{array}$ & & \\
\hline \multicolumn{8}{|l|}{ Age } \\
\hline$<20$ & $0(.0)$ & $8(9.1)$ & $37(42.0)$ & $25(28.4)$ & $18(20.5)$ & $55.822 \mathrm{a}$ & .000 \\
\hline 20-30 & $38(11.5)$ & $33(10.0)$ & $179(54.1)$ & $73(22.1)$ & $8(2.4)$ & 54.618 & .000 \\
\hline $30-40$ & $3(11.5)$ & $1(3.80$ & $13(50.0)$ & $9(34.6)$ & $0(.0)$ & & \\
\hline \multicolumn{8}{|l|}{ Ethnicity } \\
\hline Brahmin/Chhetri & 19(14.0) & $13(9.6)$ & $75(55.1)$ & $29(21.3)$ & $0(.0)$ & $24.939 \mathrm{a}$ & .002 \\
\hline Janjati & $12(5.9)$ & $17(8.3)$ & $101(49.3)$ & $53(25.9)$ & $22(10.7)$ & & \\
\hline $\begin{array}{l}\text { Madhesi/Dalit \& } \\
\text { others }\end{array}$ & $10(9.6)$ & $12(11.5)$ & $53(51.0)$ & $25(24.0)$ & $4(3.8)$ & & \\
\hline \multicolumn{8}{|l|}{ Educational Status } \\
\hline Educated & $38(9.8)$ & $39(10.1)$ & $198(51.3)$ & $90(23.3)$ & $21(5.4)$ & $4.089 \mathrm{a}$ & .394 \\
\hline Uneducated & $3(5.1)$ & $3(5.1)$ & $31(52.5)$ & $17(28.8)$ & $5(8.5)$ & 4.420 & .352 \\
\hline \multicolumn{8}{|l|}{ Occupation } \\
\hline Unemployed & $10(4.4)$ & $29(12.8)$ & $113(50.0)$ & $61(27.0)$ & $13(5.8)$ & $18.888 \mathrm{a}$ & .001 \\
\hline Employed & $31(14.2)$ & $13(5.9)$ & $116(53.0)$ & $46(21.0)$ & $13(5.9)$ & & \\
\hline \multicolumn{8}{|l|}{ Monthly income } \\
\hline$\leq 20000$ & $18(6.8)$ & $23(8.7)$ & $129(49.0)$ & $68(25.9)$ & $25(9.5)$ & $20.616 a$ & .000 \\
\hline$>20000$ & $23(12.6)$ & 19910.4) & $100(54.9)$ & $39(21.4)$ & $1(.5)$ & & \\
\hline $\begin{array}{l}\text { Spouse's } \\
\text { Occupation }\end{array}$ & & & & & & & \\
\hline
\end{tabular}




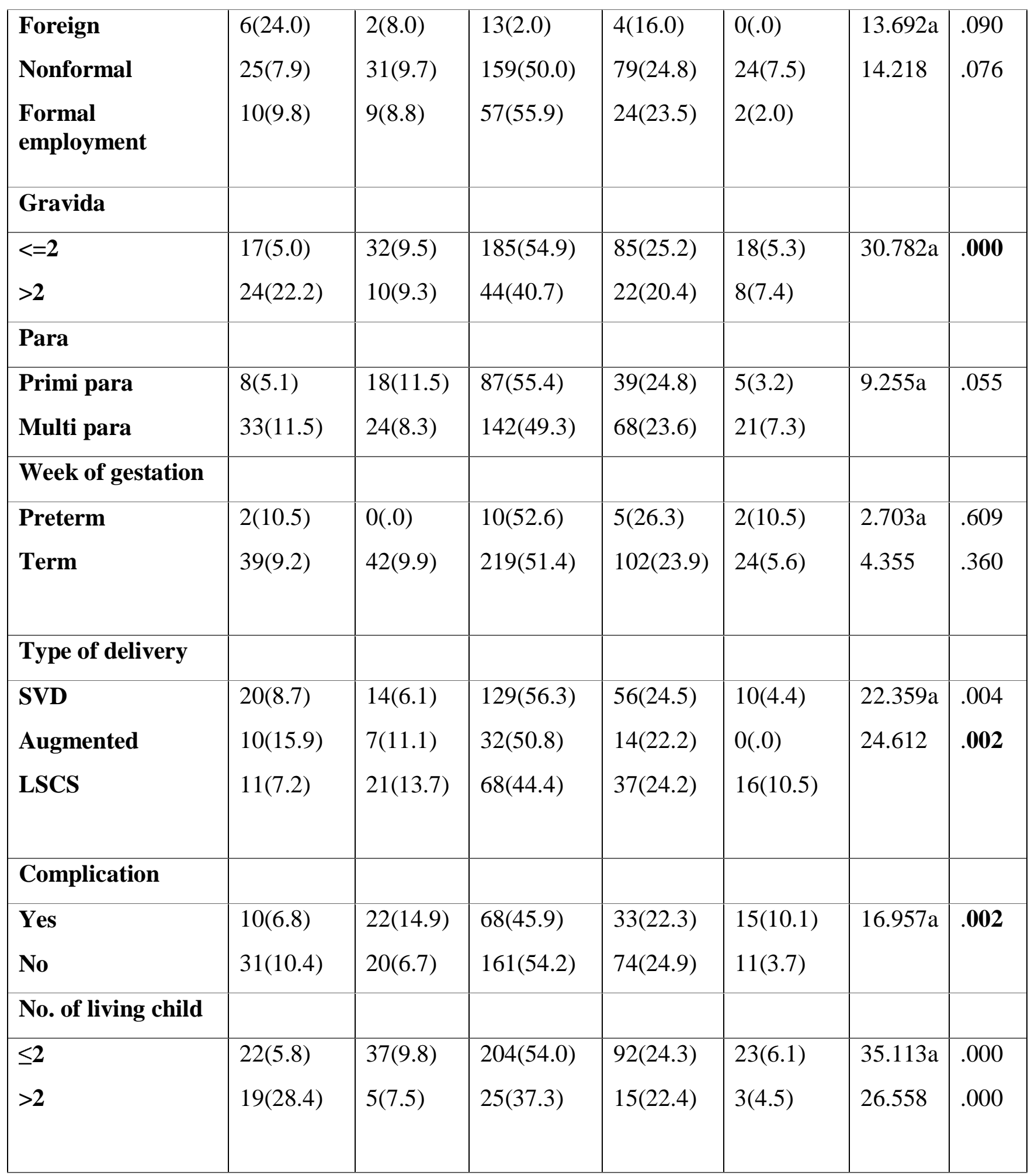

522 Table 8. Associated factors for Timely RMC during delivery $(n=445)$ 


\begin{tabular}{|c|c|c|c|c|}
\hline \multirow[t]{2}{*}{ Predictors } & \multicolumn{2}{|c|}{ Neutral RMC } & \multicolumn{2}{|c|}{ High RMC } \\
\hline & OR( CI $)$ & P-Value & OR(CI) & P-Value \\
\hline \multicolumn{5}{|c|}{ Type of Delivery } \\
\hline SVD & $2.07(1.15-3.72)$ & 0.01 & $1.38(0.74-2.59)$ & 0.30 \\
\hline Augmented & $0.99(0.47-2.10)$ & 0.99 & $0.56(0.23-1.36)$ & 0.18 \\
\hline LSCS & $0^{b}$ & - & $0^{\mathrm{b}}$ & - \\
\hline \multicolumn{5}{|l|}{ Gravida } \\
\hline Primi & $2.28(0.92-6.29)$ & 0.07 & $2.20(0.82-5.90)$ & 0.12 \\
\hline Multi & $0^{\mathrm{b}}$ & & $0^{\mathrm{b}}$ & - \\
\hline \multicolumn{5}{|c|}{ Monthly income (NPR) } \\
\hline$\leq 20000$ & $1.33(0.78-2.24)$ & 0.289 & $2.36(1.3-4.23)$ & 0.004 \\
\hline$>20000$ & $0^{\mathrm{b}}$ & - & $0^{\mathrm{b}}$ & \\
\hline \multicolumn{5}{|c|}{ Complication during delivery } \\
\hline Yes & $0.81(0.43-1.53)$ & 0.52 & $0.63(0.31-1.27)$ & 0.63 \\
\hline No & $0^{\mathrm{b}}$ & - & $0^{\mathrm{b}}$ & \\
\hline \multicolumn{5}{|c|}{ Living Children } \\
\hline$\leq 2$ & $1.86(0.74-2.59)$ & 0.048 & $1.52(0.52-4.39)$ & 0.43 \\
\hline$\geq 2$ & $0^{b}$ & - & $0^{\mathrm{b}}$ & - \\
\hline
\end{tabular}

523 Model fitting information $=$ Chi-square $=3.68, \mathrm{df}=12 \mathrm{p}$-value $=0.000$, Pseudo $\mathrm{R}^{2}$ Nagelkerke $=0.096$

524 a. The reference category is 1.00 Low RMC, b This parameter set zero because it is redundant, 525 